\title{
RAPE CASES: GENRE AND RHETORICAL ANALYSIS OF CONTROVERSIAL MALAYSIAN LEGAL JUDGEMENTS
}

\author{
Maya Khemlani David \\ University of Malaya, Malaysia \\ Email: mayadavid@yahoo.com \\ Neda Saeipoor \\ University of Malaya, Malaysia \\ Email: nsaeipour@yahoo.com \\ Mumtaz Ali \\ University of Karachi, Pakistan \\ E-mail: mumtaz.human@gmail.com
}

APA Citation: David, M. K., Saeipoor, N., \& Ali, M. (2016). Rape cases: Genre and rhetorical analysis of controversial Malaysian legal judgement. English Review: Journal of English Education, 5(1), 71-78

Published: 01-12-2016

\begin{abstract}
Kachru and Smith (2008) emphasize that effectual communication in the context in which different varieties of world English are used, entails awareness of the varieties in use and their cultural, social, and ideational functions. Court reports by Malaysian Judges are part of legal documents, which may be considered as a genre. Investigating the linguistic details of these reports may be helpful in understanding the argumentative and persuasive strategies used in these judgments. The issue of rape and justice is an important concern in society. The aim of this study is to investigate Malaysian judgment reports in the English language on rape cases from a linguistic perspective. Specifically, the aim of the study is to identify court of appeal judgment reports of rape cases as a Genre and to identify the moves used in this genre. The moves within the genre were identified by studying two controversial reports which showed that the judgments might suffer from relying on pathos argumentation in one critical move.
\end{abstract}

Keywords: language, law, legal, judgment, Malaysia and courts

\section{INTRODUCTION}

The literature on language and the law is replete with references to the central importance of language in the legal process. Given the close relationship between Language and Law, it is not surprising that both lawyers and applied linguists have devoted considerable time and energy to the description of legal texts and associated legal literacy practices (Hafner, 2010). According to Richards, Gillespie, \& Smith (2014) in most cases ${ }^{\prime} L a w$ enforcement officers are often first responders and are most likely to provide news media with a description of the crime'.

The present study seeks to utilize interconnecting bridges between language and law in order to reveal the fundamental moves in this professional genre in the courts of appeal in Malaysia with a focus on rape cases. The legal support in interpreting the rape cases is important (Barnes \& Stringer, 2014).

In a paper on blame attribution in rape cases Finch and Munro (2005) said 
that the merger of provision of statutory and common law are criticized as illequipped to deal with the intricacies of modern sexual (mis) behavior. While Bentham and other scholars such as Wittgenstein looked at the relationship between language and law from a philosophical and even political point of view, other scholars have sought to address other levels of relationship between language and law.

Castero (1991) for instance studied criminal appeal cases in the Philippines and attempted to establish the appeal case as a unique genre in itself. He applied Bhatia's model and concluded that the arrangements of the different moves of a legal case are structured and the sequence in which they occur are shaped by shared conventions.

In Malaysia, interdisciplinary work on linguistics and law is a relatively new area of study. A few Malaysian scholars have selected Malaysian courts to study different aspects of language and its interrelations with Law in general and court reports in particular. Several comprehensive studies have examined the linguistic aspects of court interactions and documents from different perspectives. For example, Zubaidah Ibrahim (2002) studied the adequacy of interpreting services and the effectiveness of the Malaysian judicial system in providing such services in courts by exploring roles and expectations. She questions the insufficiency of interpreting systems, which affect the quality of judicial process, and secondly absence of proper supervision which adversely affects the reliability of the system. Other studies including Nadzimah's (2008) have looked at language choice and use among practitioners who deal with justice and order through the language of law. Another example of such linguistic/law interdisciplinary research in Malaysia is Noraini (2007) who studied proceedings in the criminal courts of Kuala Lumpur. Her study looks at the issue of chosen language, specifically those other than Bahasa Malaysia (Malay Language). The Language Act of Malaysia asserts that Bahasa Malaysia is the medium of national communication and is used in all government departments.

At the turning point of the millennium, the Malaysian government decided to establish "a full-fledged ministry that demonstrates the government's commitment to raise the status of women in this country", first called as "the Ministry of women's affairs" the Ministry of Women, Family and Community development has since been aiming for empowerment of women, promoting gender equality and securing women's rights by setting strategies for related department and organizations as well as carrying out short and long term projects in order to enhance the situation of women.

Among different aspects of women and children issues, the phenomenon of rape can be considered as one of the most crucial and widespread problems worldwide and Malaysia is not an exception. The matter is not only limited to the rights of women but the public health and psychological problems for women are related with domestic violence and rape (Richards, Gillespie, Smith, 2014). According to the 2005 annual report of Malaysian government to the United Nations Asia and Far East Institute for the Prevention of Crime and the Treatment of Offenders (UNAFEI), regarding the issue of rape in Malaysia, most of the abused, suffer in silence because they are not aware of the law and their rights and potential available 
ENGLISH REVIEW: Journal of English Education Vol. 5, Issue 1, December 2016
ISSN 2301-7554

https://journal.uniku.ac.id/index.php/ERJEE protections (UNAFEI, 2005). According to Women Aid Organization (WAO) and based on Royal Police data, rape cases increased by more than $100 \%$ between 2000 and 2012.

The present study seeks to shed light at a darker corner of women's status in Malaysia by looking at the rape cases from a linguistic point of view, in order to unearth the fundamental arguments in the reports of judges in rape cases. The significance of this issue is emphasized by the social and public interest devoted to the subject in social public media both online and offline. Malaysian public's awareness about rape cases, judgments on rape cases and the judicial system rules and regulations with regard to rape is reflected in the media in the form of protests, petitions and articles in newspapers, blogs, forums and online social networks.

There is no known work on the Generic structure of Malaysian Rape Appeal Case Reports, which may be used by law students, lawyers, and judges as a source of information or reference. Providing a clear picture of underlying steps in these reports might be helpful for law students and practitioners.

Different linguistic theories have been used to study written and oral legal discourses. Interdisciplinary studies in Law and Linguistics have approached legal discourse using various methods and theories such as discourse analysis, critical discourse analysis, rhetoric arguments, speech act theory, politeness theories, etc. Considering our data and objectives we have decided to use a genre analysis approach to analyze rape case judgment reports of the court of appeal in Malaysia. The framework for genre analysis used in this study is now presented.
One of the basic concepts in genre analysis is the discourse community, which according to Swales (1990) is a discourse in a community who shares a common public goal and has an intercommunication system and mechanism. Discourse community has its own discoursal conventions, thus genre can be considered as communicative events by members of a discourse community, which is conventionalized through some explicit or implicit principles. Some of the comprehensive works in this area that studied moves and steps in a genre include Swales' work (1990) on introduction to research articles that creates the CARS model, Bhatia's work (1993) on sales promotion letters, and Bunton's study (2005) on PhD thesis genre. Bhatia (1991) and Candlin (2003) have published on professional genre especially in legal discourse. Bhatia (1997) explains the multidisciplinary nature of the generic framework and states genre analysis is "The study of situated linguistic behavior in institutionalized academic or professional settings". Earlier Martin (1984) sought to describe rhetorical action in discourse.

Regardless of field of study, genre analysis is an academic approach to decipher the structural approaches of a known discourse and to unearth the underlying strategies of a discourse to achieve a certain goal through the realm of language.

Judges' stance can affect the nature and formulation of their judgment. This can lead to variation in judgments, a consequence of which may be risk of a loss of trust. The particular stance taken by judges in their arguments is linguistically manifested in judgment reports. Analyzing these legal reports from a genre perspective may serve to 
provide useful information on such variation and thereby enable the avoidance of social risk and the building of trust.

Mazzi (2007) conducted a multinational genre analysis, comparing European communities, UK and Ireland. He reinforces the linguistic component of the analysis of legal on the argumentative discourse of judicial decisions by combining the perspectives of genre and corpus analysis. His focus is on the generic structure of the judgments concentrating on the more argumentative move of it, i.e. arguing the case. La Free, as far back as 1980 said that response on reaction toward rape seemed flawed by theoretical and methodological problems that have prevented a reliable determinants assessment (La Free, 1980).

The analysis by Mazzi (2007) was carried out on a small corpus of 40 judgments, 20 of which were delivered by the Court of Justice of the European Communities, and ten by the House of Lords (UK) and Irelands's Supreme Court respectively. The corpus amounted to 425,502 words, and was designed according to two basic criteria: first of all, three courts of last instance were chosen, in order to ensure the homogeneity of corpus data and at the same time provide for a comparative framework provided by the inevitable differences among jurisdictions (European, English and Irish) and legal systems (EC v. Common Law). The small corpus was randomly drawn from a larger reference corpus of 221 judgments $(1,646,502$ words) that had previously been created along the same guidelines. Bhatia's model was taken as a standard reference, in order to re-construct the generic structure of the three types of judgments included in the corpus.
The careful reading of all corpus texts revealed that English and Irish judgments share the generic structure reported below:

- Identifying the case

- Establishing facts of the case

- Arguing the case

- Stating history of the case

- Identifying the conflict of categorization

- Presenting arguments

- Deriving ratio decidendi

- Pronouncing judgment

This structure is close to Bhatia's model in that it also features the four main moves Identifying the case, Establishing facts of the case, Arguing the case and Pronouncing judgment. However, it distances itself from it, since Arguing the case is sub-divided into four rather than three sub-moves.

When identifying the conflict of categorization it may be anticipated that through that move the judge explicitly acknowledges his categorization of the facts of the case, i.e. his interpretation of them under the appropriate predetermined legal category (e.g. murder v. manslaughter), and this may clash with an alternative categorization proposed by other subjects such as the representatives of a party in the dispute, another judge of the same bench or another court of the jurisdiction. On the other hand, EC judgments appear to be characterized by the slightly different generic structure reproduced below:

- Identifying the case

- Identifying the scope of proceedings before the Court

- Retrieving relevant Community and/or national legislation

- Stating history of the case

- Arguing the case

- Arguments of the parties

- Arguments of the Court 
ENGLISH REVIEW: Journal of English Education Vol. 5, Issue 1, December 2016
ISSN 2301-7554

https://journal.uniku.ac.id/index.php/ERJEE
- Settling costs

- Pronouncing judgment

Even if European judgments are on an average shorter than English and Irish ones, they are nonetheless articulated into more moves. For instance, a section of judgments is devoted to the identification of the scope of proceedings before the Court in terms of: when did who bring what action against whom, and before judgment is pronounced, the Court decides who is to bear costs. Moreover, a peculiarity of European judgments lies in the Courts accurate retrieval of relevant legislation at both a Community and a Member State level: this move is all the more important when the dispute is considered to center on an alleged incompatibility between EC law and national legislations.

In addition, it is noteworthy that arguing the case is realized more briefly than in English and Irish judgments, because it is limited to a summary of the parties opposed lines of argument followed by the Court's own argumentation.

English/Irish and EC judgments both belong to the judicial genre, because they are both governed by the "discourse community" (Swales, 1990, p. 9) of judges, whose communicative purpose is to settle a dispute by presenting wellfounded arguments in support of a judicial conclusion through which a number of more or less controversial facts are interpreted within the framework of a valid legal order.

\section{METHOD}

The purpose of this study was to reveal fundamental contributing segments of language in court reports in the courts of appeal in Malaysia with a focus on rape cases. Considering the unique nature of the court of appeal judgment reports genre analysis was selected as a suitable technique to analyze the data. Judgment reports can be defined as a genre based on Bhatia (1997, p. 205) who defines genre as "the study of situated linguistic behavior in institutionalized academic or professional settings." The reports in this study are analyzed based on Bhatia's seven Steps for Genre Analysis:

1. Determine the situational context

2. Survey literature

3. Refining the contextual analysis

- Speaker/Writer and Hearer/Audience

- History of discourse community

- Network of texts

- Subject/Topic

4. Select corpus

5. Study how the genre is used

6. Choose focal level for analysis

- Lexico-grammatical features

- Textualization (text-patterning)

- Structural analysis

- Cognitive move structure' (focus on purpose)

7. Get opinions of specialist informants Objectives of the present study include: Identifying the Genre moves in court of appeal Judgment reports in two controversial rape cases and identifying the rhetorical arguments in different moves in these judgments.

Based on LexisNexis database (Online authoritative sources (which are relied upon by legal professionals) such as Halsbury's Laws of Malaysia, Malaysian precedents and Forms, Atkin's Court Forms Malaysia, etc.) we accessed 242 judgment reports related to rape cases from different criminal courts in East and West Malaysia. 103 cases concerning rape and murder were excluded because the victim was killed .The cases in the Malay language from the "Mahkamah" (religious) courts were also excluded. We focused 
on statutory rape cases $(n=102)$ and two 2 controversial cases were selected for analysis.

\section{RESULTS AND DISCUSSION}

A total of 313 cases of rape were judged between 1963 and 2012. Out of these documented cases the ones including other offences like murder, defamation, outraging modesty and other unrelated cases were deleted and 112 homogenous rape cases were collected and studied as a genre to find the general moves as well as submoves within them. Five moves were distinguished to be common in all the reports: Preambles, Body of the case, Appeal Explanation, Arguing the case and Final sentence. These moves and their relevant sub-moves are classified below:

\section{Preambles}

- Name of the alleged rapist

- Name of the court

- Name of attorney

- Identification number

- Date

- Summary of the nature of the case

- $\quad$ Particular to the case or their representatives

o From the appellant, plaintiff

o From the respondent, defendant

o Judge's name

\section{Body of the case}

- Explanation about the case History of the case

- Previous court's judgment

- Grounds of last court's sentence

- Scenario of the rape

3. Explaining the Appeal

- Appellant reasons

4. Arguing the case

- Referring to other cases
- Referring to existing Evidence

o Medical tests

o Extract of Testimonies

o Reasons

- Wrapping up the reasons (Conclusion)

\section{Final Sentence}

- Declaration of Allowing or dismissing the appeal

- (Name of the reporter) The last part of the reports is declaration of the final sentence including the enhancement or mitigation of the sentence as well as restating whether the appeal has been allowed or dismissed.

\section{Rhetorical Analysis}

Rhetorical analysis is an attempt to categorize the different aspects of the argumentation of the creator of an utterance. The Argumentations are grouped in three major categories:

1. Ethos (ethical appeal): writer's credibility/qualifications to justify the argument made.

2. Logos (logical appeal): the occasions where the judge mentions reasons and evidences in his argument.

3. Pathos (pathetic appeal): tries to make use of the audience's emotions for persuading the audience to attain approval, for instance creating sympathy or antagonism.

Accountability, expertise and professionalism are the basic elements of efficient and reliable investigations and judgments (Fahsing \& Ask, 2015). According to Sagana, Sauerland \& Merckelbach (2015) critical legal practices create complications in decision-making processes. The moves and sub-moves were similar in both cases. The rhetorical arguments were 
used only in the move named "Arguing the Case". The analysis of the reports showed the tendency of the judges towards "pathos" backed with "ethos" emphasizing on the emotional aspects to raise the audience's sympathy to approve the judgment. The judges also emphasized their authority to justify the sentence. "Logos" on the other hand is used only in 2 or 3 sections in each report. The Rhetorical argument pattern in the "Arguing the Case" move may help professionals avoid the risk of the effect of personal and emotional views. This can cost a loss of trust in the judicial system.

The selected data was analyzed based on the above frameworks. There is a profound use of pathos. This argument is used several times to arose the audience's sympathy and justify the sentence especially in the controversial cases in which the judges have shown a greater tendency to victimize the victim and make her share some of the responsibility for the occurrence of the crime and in this way explain the reduced sentence on the alleged rapist. This attitude is justified by drawing the audience's attention to emotional aspects of the case more than the logical aspects. Both cases show a fair amount of the use of pathos as a rhetorical device.

\section{CONCLUSION}

Bhatia (2008) argues that studies of professional genres and professional practices complement each other, in that they not only influence each other but also are often co-constructed in specific professional contexts. He emphasizes the function of interdiscursivity in critical genre analysis by drawing examples from a range of professional contexts for a shift towards an integration of discursive and professional practices.
This view of professional discourse would account for and, to a large degree, integrate professional discourse and professional practice into a single framework.

The moves and sub-moves were similar in the cases studied, allowing us to call the judgment reports of court of appeal for rape cases in Malaysia "a Genre" which law professionals and their audience use and understand.

The rhetorical arguments were used only in the move named "Arguing the Case". The analysis of the reports showed the tendency of the judges in these two controversial cases to move more towards "pathos" thus emphasizing the emotional aspects of the case and in this way logically explain the reduced sentence on the alleged rapists.

\section{REFERENCES}

Barnes, S. L., \& Stringer, E. C. (2014). Is motherhood important? Imprisoned women's maternal experiences before and during confinement and their postrelease expectations. Feminist Criminology, 9 (1), pp. 3-23.

Bhatia, Vijay K. (1997). Translating legal genres. In: A. Trosborg, ed. Text typology and translation, Amsterdam/Philadelphia: John Benjamin Publishing Company. (n.d.). Retrieved November 23, 2013, from Ministry of Women, Family and Community Development: http:/ / www.kpwkm.g ov.my/latar-belakang

Bunton, D. (2005). The structure of PhD conclusion chapters. Journal of English for Specific Purposes, 4, pp. 207-224.

Christoph A., \& Hafner. (2010). A multiperspective genre analysis of the Barrister's opinion: Writing context, generic structure, and textualization written communication 27, pp. 410. http://wcx.sagepub.com/content/27/ 4/410. 
Fahsing, I., \& Ask, K. (2015). The making of an expert detective: The role of experience in English and Norwegian police officers' investigative decisionmaking. Psychology, Crime $\mathcal{E}$ Law, pp. 1-21.

Finch, E., \& Munro, V. E. (2005). Juror stereotypes and blame attribution in rape cases involving intoxicants the findings of a pilot study. British Journal of Criminology, 45(1), pp. 25-38.

Kachru, Y. \& Smith, L. E. (2008) Cultures, Contexts, and World Englishes. Routledge. New York, London.

La Free, G. D. (1980). Variables affecting guilty pleas and convictions in rape cases: Toward a social theory of rape processing. Social Forces, 58(3).

Mellinkoff, D. (1963). The Language of The Law. Little Brown and Co.

Sleney, J., Clarke, A., \& Moran Ellis, J. (2002). Attitudes to Date Rape and Relationship Rape: A Qualitative Study. United Nations Asia and Far East Institute for the Prevention of Crime and the Treatment of Offenders. (n.d.).
Retrieved October 25, 2013, from

UNAFEI:

http://www.unafei.or.jp/english/pdf /RS_No69/No69_15PA_Jonit.pdf

Richards, T. N., Gillespie, L. K. \& Smith, M. D. (2014). An examination of the media portrayal of femicide-suicides: An exploratory frame analysis. Feminist Criminology, 9 (1). Pp. 24-44.

Sagana, A., Sauerland, M., \& Merckelbach, H. (2015). The effect of choice reversals on blindness for identification decisions. Psychology, Crime $\mathcal{E}$ Law, (just-accepted), pp. 1-25.

Swales, J. (1990). Genre analysis: English in academic and research settings. Cambridge: Cambridge. UP.

Yamuna Kachru, Y. \& Nelson, C. L. (2006). World Englishes in Asian Contexts. Hong Kong University Press.

Yan, L. S., Chin Abdullah, M., Ju Lin, O., \& Peck Lin, W. (2002). An Overview of Rape in Malaysia. Strategic info Research Development. 